\title{
Chromosomal evolution in allopatric populations of the Odontophrynus occidentalis group (Amphibia, Anura) from western Argentina
}

\author{
I.R.G. RuIz, 1,3 J.M. CEI\$," and W. BEÇAK ${ }^{1}$ \\ 1Serviço de Genética, Instituto Butantan, São Paulo, and ¿Departamento Ciencias Naturales, \\ Universidad Nacional de Rio Cuarto, Cordoba
}

Abstract. A karyological study of some populations of the Odontophrynus occidentalis group $(2 n=22)$ from Argentina is reported. Ammoniacal silver (Ag-AS) and alkaline Giemsa (CBG) staining have been performed on specimens from La Rioja, Mendoza, Malargue, Tamelen, Tapiluque, Valcheta, and Meseta de Somuncura. All populations showed active ribosomal cistrons (NORs) on chromosome 11. Some metaphases of three specimens from Mendoza and five from La Rioja also showed bands on 9. Centromeric and telomeric C-bands were common to all populations, and a block of heterochromatin on both sides of the centromere of 2 was remarkable in all but the La Rioja populations. The specimens from La Rioja showed a similar block of heteroch romatin on the short arm of 1 .

Taxonomic studies of several specimens from these localities revealed differences in larval development, glandular pattern, the size of specimens, etc. As a whole, biological as well as karyological features suggest that the isolated population at La Rioja is a separate entity, at the species level, as described elsewhere.

Cytogenetic studies employing banding techniques have revealed unexpected features in apparently identical karyotypes. In particular, specific patterns of localization of

3Dr. Ruiz's current address is Institut de Recherche en Biologie Moléculaire, Université Paris VII, 2, Place Jussieu, Tour 43, 75251 Paris Cedex 05 (France).

Supported by grants from PNUD-UNESCO RLA 78/024 and the Brazilian CNPq/FINEP, FADESP, and FEDIB.

Request reprints from: Dr. ITAMaR R.G. RuIZ, Institute de Recherche en Biologie Moléculaire, Université Paris VII, 2, Place Jussieu, Tour 43, 75251 Paris Cedex 05 (France). constitutive heterochromatin (C-bands) on chromosomes have, in many cases, accompanied other morphological modifications implied in the phenomena of biological speciation (PATHAK et al., 1973; HePPICH, 1978; HolmQUIST, 1975; Yosida and SAGAI, 1975). Also, the identification of sex-specific chromosomes, frequently homomorphic in Amphibians, has been possible in some species by means of the C-banding (SCHMID, 1979, 1980) and BrdU-Hoechst-Giemsa techniques (SCHEMPP and ScHMID, 1981).

The genus Odontophrynus includes several species of toadlike burrowers of the 
family Leptodactylidae, such as $O$. americanus, $O$. cultripes, $O$. moratoi, $O$. carvalhoi, $O$. alipioi, and $O$. occidentalis, widely distributed in South America. The C- and Ag-AS band patterns of most of these species have recently been described by RuIz et al. (1981). These patterns contribute to determining the phylogenetic relationships among them.

In the present work we describe the chromosomal localization of constitutive heterochromatin and nucleolar organizer regions of several populations of the $O$. occidentalis group in Argentina. A rearrangement involving heterochromatin combined with other specific biological characteristics was detected in one of the populations.

\section{Materials and methods}

Populations of $O$. occidentalis group from the following localities were studied (fig. 1 and table I):

1. Sierra de Famatina (Aguadita, $2200 \mathrm{~m}$, La Rioja Province);

2. Chacras de Coria $(1000 \mathrm{~m}$, near the city of Mendoza, Mendoza Province) corresponding to the typical form of $O$. occidentalis (the typical form of Ceratophrys occidentalis Berg = Odontophrynus occidentalis (Berg) is found in the subandean region of Neuquén, $650 \mathrm{~km}$ from Mendoza southwards);

3. Malargue $(350 \mathrm{~km}$ from Mendoza southwards, $1200 \mathrm{~m}$, Mendoza Province);

4. Tamelen $(190 \mathrm{~km}$ west of Valcheta, $800 \mathrm{~m}$, Rio Negro Province);

5. Tapiluque $(170 \mathrm{~km}$ west of Valcheta, $750 \mathrm{~m}$, Rio Negro Province);

6. Valcheta ( $300 \mathrm{~m}$, Rio Negro Province);

7. Meseta de Somuncura (Arroyo Ariete, $700 \mathrm{~m}$, interior of the Meseta, Rio Negro Province). Tamelen, Tapiluque, and Valcheta are also located on the septentrional borders of Meseta de Somuncura, an isolated basaltic, Patagonian plateau.

Animals were injected with $1 \%$ colchicine ( $0.1 \mathrm{ml} / 10 \mathrm{~g}$ body weight) $3 \mathrm{~h}$ before killing.
Table I. Origin and sex of $O$. occidentalis specimens from different localities of Argentina

\begin{tabular}{|c|c|c|c|c|}
\hline City (province) & $\mathbf{J} 1$ & $q$ & $\hat{o}$ & Total \\
\hline \multicolumn{5}{|l|}{ Sierra de Famatina } \\
\hline Mendoza & & & & \\
\hline (Mendoza) & 1 & 2 & 6 & 9 \\
\hline Malargue & & & & \\
\hline (Mendoza) & 1 & 3 & - & 4 \\
\hline Tamelen & & & & \\
\hline (Rio Negro) & - & - & 1 & 1 \\
\hline Tapiluque & & & & \\
\hline (Rio Negro) & - & - & 3 & 3 \\
\hline Valcheta & & & & \\
\hline (Rio Negro) & - & - & 3 & 3 \\
\hline $\begin{array}{l}\text { Meseta de Somuncura } \\
\text { (Rio Negro) }\end{array}$ & 1 & - & - & 1 \\
\hline
\end{tabular}

$1 \mathrm{~J}$ : juvenile individual.

Metaphases were obtained by squashing small fragments of intestinal epithelium, following treatment with hypotonic solution and fixative. After removing coverslips (dry-ice method) preparations were kept $10 \mathrm{~min}$ in $95 \%$ ethanol at $0^{\circ} \mathrm{C}$, and finally air-dried.

$\mathrm{C}$ and $\mathrm{Ag}$-AS banding was done according to SUMNER (1972) and GOOdPasture and BLOOM (1975), respectively, usually without modifications. However some modifications proposed by PATHAK (pers. commun.) were also tried: a few drops of a $50 \%$ aquaeous solution of $\mathrm{AgNO}_{3}$ containing 2 to 3 drops of formalin were added to the preparation, which was then covered with a coverslip and left at $65^{\circ} \mathrm{C}$ until the chromosomes reached a golden colour as checked by light microscopy. The nucleolar organizer regions (NORs) turned black. The preparation was then rinsed in deionized water and mounted in Permount. Metaphases were photographed the same day.

Five C-banded metaphases of specimens from different localities were measured and the total amount of heterochromatin as a percentage of total chromatin was coarsely estimated for each cell. The percentage of heterochromatin present on chromosomes 1 and 2 was also estimated. 
Fig. 1. Tentative distribution of the Odontophrynus occidentalis group (hatched area), and localities where specimens were collected. 1. Aguadita (Sierra de Famatina); 2. Chacras de Coria (near Mendoza); 3. Malargue; 4. Tamelen; 5. Tapiluque; 6. Valcheta; 7. Arroyo Ariete (Meseta de Somuncura). Black circle: Arroyo Agrio, Neuquén, Terra typica of Odontophrynus occidentalis (Berg). Some cities near the limits of the distribution area are indicated.

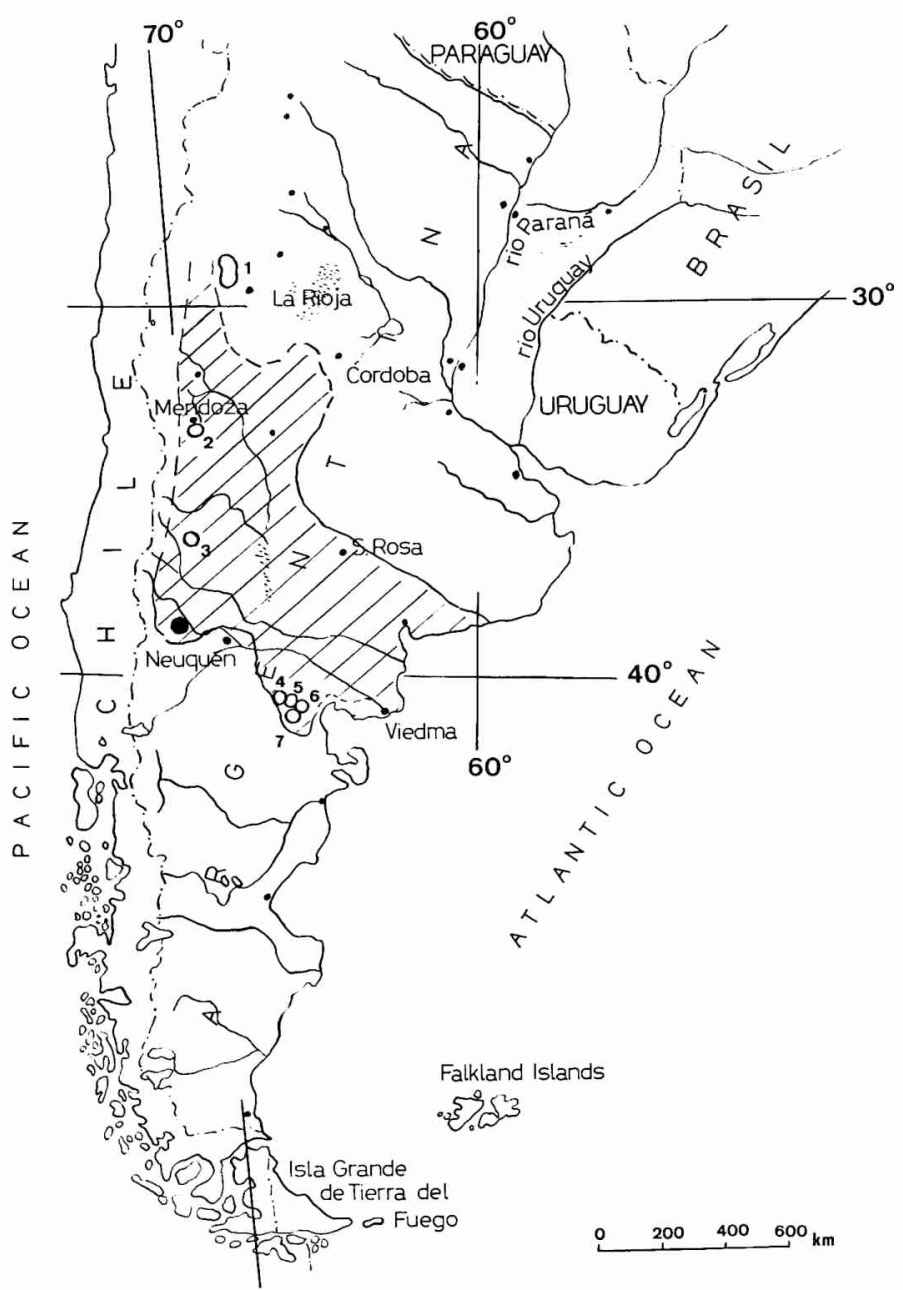

\section{Results}

\section{C-band patterns}

The specimens from all localities had constitutive heterochromatin at centromeres and, to some extent, also at telomeres. In addition to these bands, different patterns of interstitial bands were found in the populations studied.

Table II shows the polymorphic patterns of intercalary bands on chromosomes 1,2 ,
3,6 , and 9. Note the following characteristics: (1) The constitutive heterochromatin of chromosome 1 is located on the pericentromeric region of the $p$ arm and centromere, but it never reaches the q arm (fig. 3). This heterochromatic block is found in specimens from La Rioja only. (2) The constitutive heterochromatin of chromosome 2 is located mainly in the pericentromeric area of the $\mathrm{p} \mathrm{arm}$, the centromere, and a small portion of the pericentromeric area of the $q$ 
Table II. Number of cells showing polymorphism for constitutive heterochromatin of five chromosomes

\begin{tabular}{|c|c|c|c|c|c|c|c|}
\hline \multirow{2}{*}{ Chromosome } & \multicolumn{7}{|l|}{ Locality } \\
\hline & La Rioja & Mendoza & Malague & Tamelen & Tapiluque & Valcheta & $\begin{array}{l}\text { Meseta } \\
\text { de } \\
\text { Somuncura }\end{array}$ \\
\hline \multicolumn{8}{|l|}{1} \\
\hline & 49 & - & - & - & - & - & - \\
\hline & 42 & - & - & - & - & - & - \\
\hline & 28 & - & - & - & - & - & - \\
\hline \multicolumn{8}{|l|}{2} \\
\hline & - & 58 & 21 & 3 & 8 & 10 & 3 \\
\hline & - & 61 & 9 & - & 6 & 12 & 5 \\
\hline & 83 & 2 & - & - & - & - & - \\
\hline & - & 31 & - & - & - & - & - \\
\hline \multicolumn{8}{|l|}{3} \\
\hline & 19 & - & - & - & - & - & - \\
\hline & - & 35 & - & - & - & - & - \\
\hline & - & 5 & - & - & - & - & - \\
\hline \multicolumn{8}{|l|}{6} \\
\hline & 49 & 7 & 2 & - & - & 2 & - \\
\hline \multicolumn{8}{|l|}{9} \\
\hline & 98 & 65 & 11 & - & - & - & - \\
\hline Total & 119 & 119 & 30 & 3 & 14 & 22 & 8 \\
\hline
\end{tabular}

arm (fig. 2). This heterochromatin block is smaller in specimens from La Rioja. (3) Chromosome 1 is dimorphic for the size of the heterochromatic block (fig. 3c). Since all cells of an individual have the same pattern, it is probable that the amount of heterochromatin on the maternally derived 1 different from that on the paternal one. (4) Heterochromatic blocks of two different sizes were seen on 2 in the same individual depending on the cell examined (fig. $2 a$ and $b$ ). In this case, metabolic differences between cells would account for a different condensation of heterochromatin in each homologue. (5) An intercalary C-band was observed in the distal region of $2 q$ in several cells of five specimens from Mendoza (fig. 2a). (6) An intercalary C-band was observed in the medial region of $2 p$ in almost all specimens from La Rioja only (fig. 3a). (7) An intercalary C-band was observed in the distal region of $3 q$ in four specimens from Mendoza; either one or both homologues were banded (fig. 2a). (8) Intercalary bands on 6 were very weak, being hardly evident in most specimens studied (fig. $3 a$ and $b$ ). (9) An intercalary band on the distal region of $9 \mathrm{q}$ was prominent in some specimens (figs. $2 a$ and $b ; 3 a, b$, and $c$ ).

\section{Constitutive heterochromatin} measurements

Five C-banded metaphases were chosen at random from specimens of each popula- 
Fig. 2. C-banded karyotypes of specimens from three localities, showing: a. heteromorphism of a block of heterochromatin on $2 \mathrm{pq}$, intercalary bands on $2 \mathrm{q}, 3 \mathrm{q}$ (one homologue), 6q, and 9q (Mendoza); b. a block of heterochromatin on 2pq and an intercalary band on 9q (Malargue); c. heteromorphism of a block of heterochromatin on 2pq (Meseta de Somuncura). Bars equal $5 \mu \mathrm{m}$.
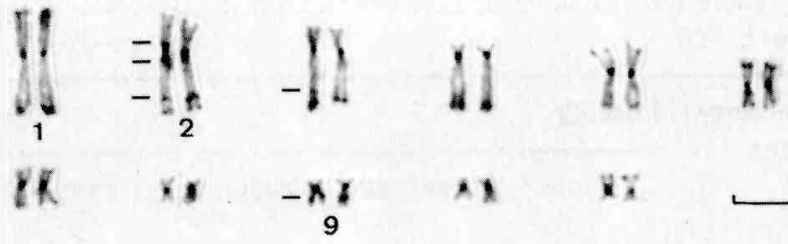

A

$x$
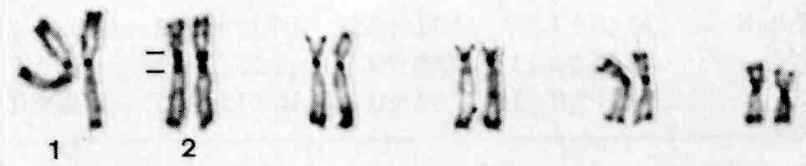

YY

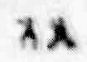

$-81$

S)

$\times 8$
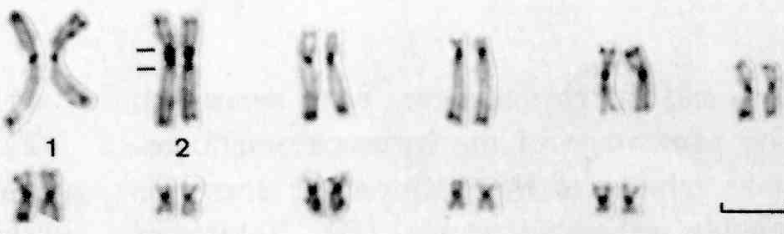

(18

\section{i $\mathrm{Y}$}

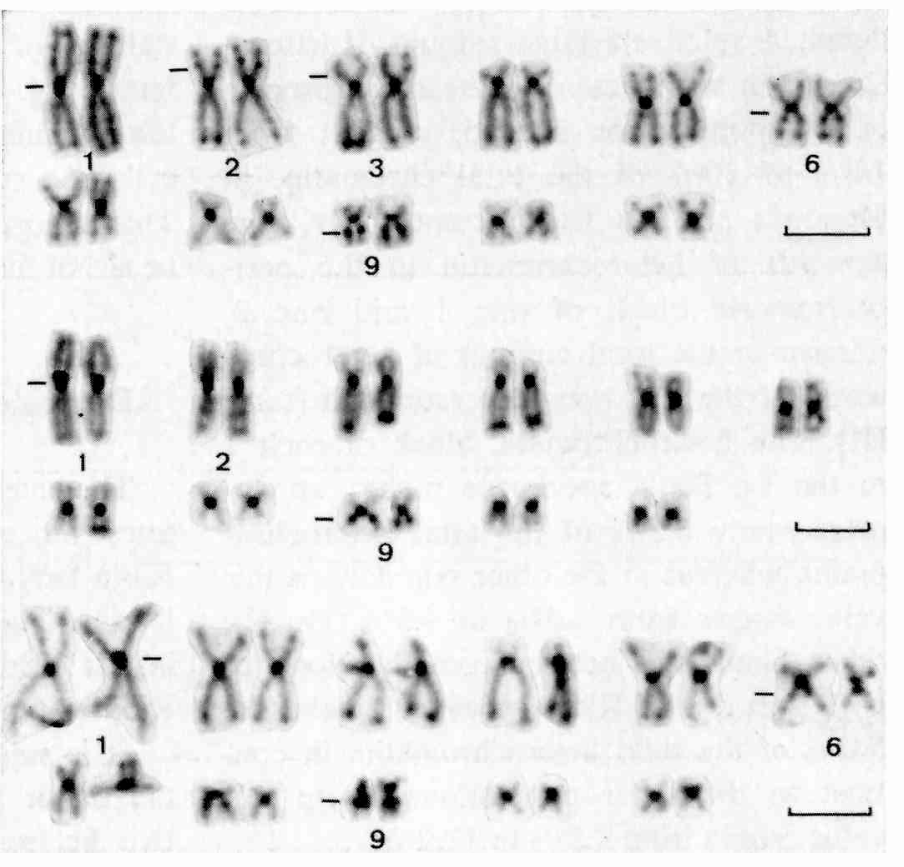

Fig. 3. Polymorphism in Cband karyotypes in specimens from La Rioja a. a block of heterochromatin on $1 p$ and intercalary bands on $2 p, 3 p, 6 q$, and $9 q ; b$. a block of heterochromatin on $1 p$, a smaller one on $2 p$, and an intercalary band on $9 \mathrm{q}$; $c$. heteromorphism of heterochromatin on $1 \mathrm{p}$ and intercalary bands on $6 \mathrm{q}$ and $9 \mathrm{q}$. Bars equal $5 \mu \mathrm{m}$. 
Table III. Amounts of heterochromatin in five cells of individuals from different localities (percentage $\pm \mathrm{SD})$

\begin{tabular}{lrrrrrrr}
\hline $\begin{array}{l}\text { Chromo- } \\
\text { some }\end{array}$ & Locality & & & & & \\
\cline { 2 - 7 } & La Rioja & Mendoza & Malargue & Tamelen & Tapiluque & Valcheta & \multicolumn{1}{c}{$\begin{array}{l}\text { Meseta de } \\
\text { Somuncura }\end{array}$} \\
& & & & & & & \\
\hline Total $^{1}$ & $20.40 \pm 1.37$ & $14.71 \pm 0.51$ & $16.42 \pm 1.02$ & $18.98 \pm 1.90$ & $16.49 \pm 1.15$ & $17.12 \pm 1.19$ & $14.61 \pm 0.61$ \\
$1^{2}$ & $6.36 \pm 0.13$ & $3.98 \pm 0.41$ & $3.65 \pm 0.11$ & $4.00 \pm 0.12$ & $4.25 \pm 0.31$ & $3.79 \pm 0.24$ & $4.25 \pm 0.24$ \\
$2^{3}$ & $4.91 \pm 0.35$ & $9.93 \pm 0.40$ & $10.87 \pm 0.38$ & $9.40 \pm 0.30$ & $9.47 \pm 0.73$ & $10.75 \pm 1.18$ & $11.16 \pm 0.81$
\end{tabular}

\footnotetext{
Percentage of heterochromatin in the full diploid set relative to total chromatin.

Percentage of heterochromatin in chromosome 1 relative to the total heterochromatin.

Percentage of heterochromatin in chromosome 2 relative to the total heterochromatin.
}

tion, and the chromosomes were measured. The percentage of the heterochromatic regions relative to the euchromatic ones was roughly estimated (table III). Telomeres were not included as heterochromatin since there is a great deal of variation from cell to cell. Only centromeres and other intercalary heterochromatic zones were considered. A relatively large amount of heterochromatin was present in the chromosomes of the populations studied, ranging from $14 \%$ to $20 \%$ of the total chromatin, in Mendoza and La Rioja, respectively. The amounts of heterochromatin in the pericentromeric block of one 1 and one 2 , relative to the total amount of heterochromatin of the cell, was also estimated (table III). The heterochromatic block of each 1 in the La Rioja specimens makes up approximately $6.5 \%$ of the total heterochromatin, whereas in the other populations this value ranges from $3.5 \%$ to $4.5 \%$. On the other hand, the heterochromatic block of each 2 in the La Rioja specimens makes up $5.0 \%$ of the total heterochromatin, in contrast to the other populations where this value ranges from $9.5 \%$ to $11.0 \%$.

\section{NOR-band patterns}

The specimens from all localities showed active ribosomal cistrons on the secondary constriction of $11 p$ (table IV; fig. 4). In addition, five specimens from La Rioja and three from Mendoza showed active cistrons on the C-positive intercalary band of the distal region of $9 q$ (fig. $4 a$ ). The intensity of staining of homologues was generally different (fig. $4 b$ and $d$ ). An extreme case was the staining of only one homologue in all cells of a specimen from La Rioja (fig. 4c). This dimorphism was independent of the sex or age of the specimens.

\section{Discussion}

The heterochromatic block of the 1 constitutes an easy way of distinguishing La Rioja karyotypes from those of other populations. The percentage of heterochromatin in this chromosomal region is greater in $\mathrm{La}$ Rioja population than in the others.

It is suggested that in these populations the major rearrangements of the constitutive heterochromatin on 1,2 , and 3 are 
Table IV. Number of cells showing active NORs on $9 q$ and 11q

\begin{tabular}{|c|c|c|c|c|c|c|c|}
\hline \multirow[t]{2}{*}{ Chromosome } & \multicolumn{7}{|l|}{ Locality } \\
\hline & La Rioja & Mendoza & Malargue & Tamelen & Tapiluque & Valcheta & $\begin{array}{l}\text { Meseta de } \\
\text { Somuncura }\end{array}$ \\
\hline \multicolumn{8}{|l|}{9} \\
\hline & 21 & 10 & - & - & - & - & - \\
\hline \multicolumn{8}{|l|}{11} \\
\hline & 29 & 14 & 20 & 1 & 11 & 27 & 5 \\
\hline & 83 & 78 & 14 & 2 & 8 & 14 & - \\
\hline & 16 & 1 & 1 & 1 & 2 & - & - \\
\hline Total & 128 & 93 & 35 & 4 & 21 & 42 & 5 \\
\hline
\end{tabular}

Fig. 4. Ag-stained NORs in karyotypes of different specimens: a. active NORs on $11 p$ and $9 q$ (La Rioja); b. and d. apparent duplication of an NOR on 11p (La Rioja and Mendoza); c. only one homologue with an active NOR on 11p (La Rioja). Bars equal $5 \mu \mathrm{m}$.

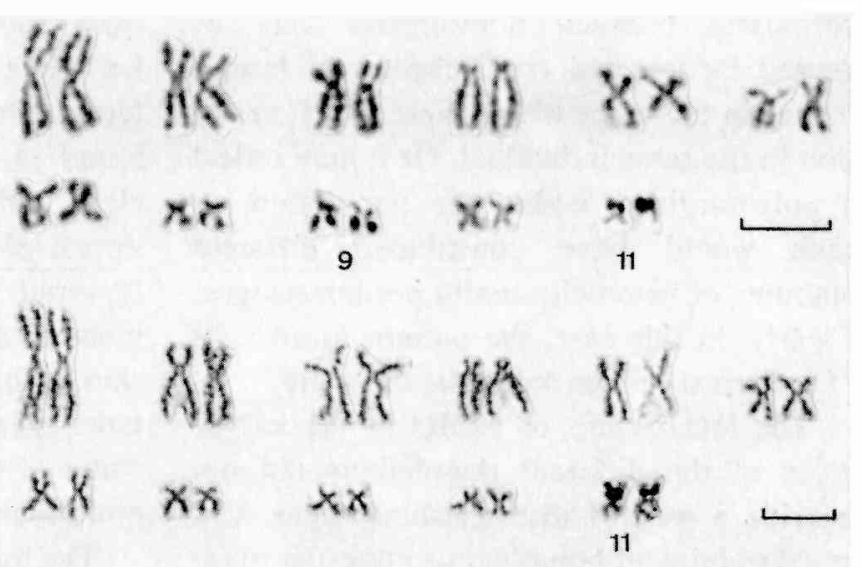

86 3x 88 56 $36 x$

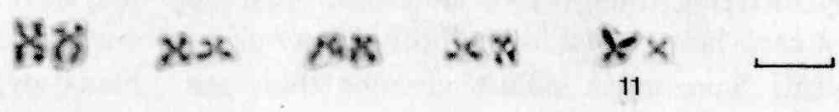

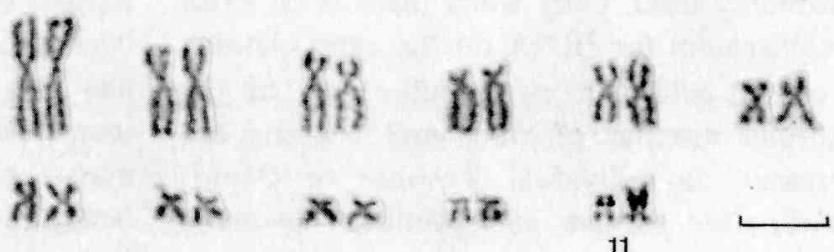
11 
apparently occurring. The pericentromeric block on 2 has already been regarded as characteristic of the genus Odontophrynus (Rurz et al., 1981), so that most populations of $O$. occidentalis examined for this pair do not differ from other species of the same genus. On the other hand, the intercalary band on 9 is typical of the $O$. occidentalis group and is not present in other species of Odontophrynus studied up to now. The pericentromeric block on 1 in the $\mathrm{La}$ Rioja specimens is an unusual rearrangement in the genus, pointing to a distinct pattern of chromosomal evolution in this population.

The observed heteromorphism of heterochromatin between homologues may be caused by unequal condensation of homologues in the cases where there is cell variation in the same individual. Or it may reflect a polymorphism within the population, as each would have contributed different amounts of heterochromatin per homologue. Clearly, in this case, the pattern in all cells of a given specimen would be the same.

The localization of NORs in the karyotypes of the different populations did not provide a way of distinguishing them. Unequal staining of homologous nucleolar organizer regions is common in many organisms. This variability may be caused by the activation of mainly one homologue in each cell, by differing numbers of ribosomal cistrons on each homologue, or by both. Many organisms have more rDNA cistrons than are normally used. Only when there is an extra requirement for rRNA do the extra cistrons become active. Even if only $50 \%$ of the normal number of ribosomal cistrons are present, an individual Xenopus or Drosophila may survive and produce the same amount of rRNA as the wild type (MOHAN and Ritossa, 1970). One specimen from La Rioja (fig. 4c) must carry such a mutant with only $50 \%$ of these cistrons because in all 16 cells examined, only one homologue was banded. Extra sets of these genes appear to be located on $9 q$ in some specimens from La Rioja and Mendoza, although rarely active in all cells. It is possible that some of these genes on 9 are present in specimens from other populations, but they have not been detected in the present study.

The populations of the $O$. occidentalis group extend through a wide range in western Argentina, from about $28^{\circ}$ to $41^{\circ}$ south latitude and from about $60^{\circ}$ to $70^{\circ}$ west longitude, being scattered in altitude from $250 \mathrm{~m}$ (Valcheta) to $2,300 \mathrm{~m}$ in the La Rioja mountains (fig. 1). In their different habitats the animals are normally found in dry, stony, and sandy soils, near clear, running streams or springs on the slopes of the mountains. They are typical fossorial anurans and can survive several months of starvation underground. Their skin is hard and glandular, and the large tadpoles may live a long time in the shallow water of ponds and streamlets before metamorphosis.

The limited and localized population from Aguadita Springs, La Rioja, is found at $2,200 \mathrm{~m}$, in a massif which became isolated from the surrounding mountains by glaciation in the Pleistocene. Selective factors here may have hastened adaptative speciation in many organisms. A number of species of reptiles endemic to this region have recently been described (CEI, 1980). The isolation has also apparently prevented them from interbreeding with other populations. This may explain why the karyological diversification described here was acquired and maintained. 
The importance of the maintenance of distinct patterns of heterochromatin in a given species has not been convincingly explained. It has been emphasized that the repeated sequences included in heterochromatic zones facilitate recombinational events, the variation being probably related to clinal relationship and fitness (JOHN and Miklos, 1979). Chromosomal evolution must have paralleled other morphological changes in a broader genetic process implied in speciation. Indeed, specimens from La Rioja show several morphological characteristics, e.g., skin structure, glandular distribution pattern, morphometric parameters, larval morphology, life cycle, etc., which differ from those of other populations of the $O$. occidentalis group. These features were taken together to support a true specific status of La Rioja populations, as discussed elsewhere (CFI et al., 1982).

\section{Acknowledgements}

Special thanks are due to Ing. A. Scolaro from the Centro Nacional Patagonico, Puerto Madryn, Chubut, for cooperation in collecting samples of o. occidentalis in several localities of Patagonia, Argentina. We also acknowledge T.M.B. DE ALMEIDA for help in experimental procedures, M. BRIENT for typing the manuscript, and R. LOVELL-BADGE for correcting the English.

\section{References}

CeI, J.M.: New endemic Iguanid lizards from the Famatina mountains of western Argentina. J. Herpetol. 14: 57-64 (1980).

CEI, J.M.; RuIz, I.R.G., and BEÇAK, W.: Odontophrynus barrioi, a new species of anuran from Argentina. J. Herpetol. (1982, in press).

Goodpasture, C. and Bloom, S.E.: Visualization of nucleolar organizer regions in mammalian chromosomes using silver staining. Chromosoma 53: 37-50 (1975).

Heppich, S.: Hybridogenesis in Rana lessonae and Rana esculenta. Z. zool. syst. Evolut. Forsch. 16: 27-39 (1978).

HolmQuist, G.: Organization and evolution of Drosophila virilis heterochromatin. Nature, Lond. 257: 503-506 (1975).

JoHN, B. and MikLos, G.L.G.: Functional aspects of satellite DNA and heterochromatin. Int. Rev. Cytol. 58: 1-114 (1979).

MoHAN, J. and RitosSA, F.M.: Regulation of ribosomal RNA synthesis and its bearing on the bobbed phenotype in Drosophila melanogaster. Devel. Biol. 22: 495-512 (1970).

PathaK, S.; Hsu, T.C., and ARrighI, F.E.: Chromosomes of Peromyscus (Rodentia, Cricetidae). IV. The role of heterochromatin in karyotypic evolution. Cytogenet. Cell Genet. 12: 315-326 (1973).

RuIz, I.R.G.; SOMA, M., and BEçAK, W.: Nucleolar organizer regions and constitutive heterochromatin in polyploid species of the genus Odontophrynus (Amphibia, Anura). Cytogenet. Cell Genet. 29: 84-98 (1981).

SCHEMPP, W. and SCHMiD, M.: Chromosome banding in Amphibia. VI. BrdU-replication patterns in Anura and demonstration of $\mathrm{XX} / \mathrm{XY}$ chromosomes in Rana esculenta. Chromosoma 83: 697-710 (1981).

SCHMID, M.: Chromosome banding in Amphibia. V. Highly differentiated $\mathrm{ZW} / \mathrm{ZZ}$ sex chromosomes and exceptional genome size in Pyxicephalus adspersus (Anura, Ranidae). Chromosoma 80: 69-96 (1980).

SCHMID, M.; OlerT, J., and KletT, C.: Chromosome banding in Amphibia. III. Sex chromosomes in Triturus. Chromosoma 71: 29-55 (1979).

SumNER, A.T.: A simple technique for demonstrating centromeric heterochromatin. Expl Cell Res. 75: 304-306 (1972).

Yosida, T.H. and SAGAI, T.: Variation of C-bands in the chromosomes of several subspecies of Rattus rattus. Chromosoma 50: 283-300 (1975).

Received: 18 November 1981

Accepted: 20 January 1982 